\title{
Measuring Mobile Service Satisfaction: Factor Analysis Based Study on Mobile Users of Gujarat
}

\author{
Sukanta Saha, Yogesh C Joshi
}

\begin{abstract}
Determination of customer satisfaction is one of the very important parameters for the telecom operators in India. This paper undertakes analysis of different factors, which enables to ear mark the major aspects that leads to satisfaction of mobile users. The study had been carried out among the mobile users of the state of Gujarat. The paper also tries to find out the gaps between customer expectation and their service satisfaction. The study also investigates the potentiality of the revenue generation and customer retention tools for telecom operators. Opinions of about 800 mobile users from 20 districts of Gujarat were captured through close ended questionnaire. Simple random sampling method was used, where the perception of individuals of various strata of the society were captured. Other than recording the personal data of the mobile users, in terms of name, age, gender, locality, profession, income and qualification, other useful information related to satisfaction from mobile services were also captured. Levels of satisfaction of the respondents were recorded using Likert 5-Point scale system. Statistical tool SPSS was used for the dimension reduction and identification of the significant factors using factor analysis. 19 attributes of satisfaction were grouped in 5 important factors with their respective factor loadings. These factors ensures enhancement of the customer experience as well as boosting service quality, which helps in devising suitable sustainable strategies for the mobile market today. Further the levels of satisfaction of the mobile users of Gujarat were also analyzed with respect to various zones, urban-rural, age groups as well as income categories. These conclusive evidences may help the telecom players to enhance and retain their existing customer base as well as revenue.
\end{abstract}

Index Terms: Perception, Factor Analysis, Principal Component, Factor Loading

\section{INTRODUCTION}

Telecom services have now become the need of the hour. Its transition from a luxury item has all been attributed by virtue of policy evolutions and change in mentality of the law makers. Its presence is now felt in every nook and corner of the society. The root of all development activities of the government in some way or the other boils down to telecom services. Digital India, a pioneer project of Government of India, is completely dependent on Telecom services. The touch of digitization is felt in every aspects of life whether it is banking, shopping, communicating and thus we are

Revised Manuscript Received on July 13, 2019.

* Correspondence Author

Sukanta Saha*, Ph.D. Scholar, Sardar Patel University, Vallabh Vidyanagar, Anand, Gujarat-388120, India.

Yogesh C Joshi, Dean, Faculty of Management, Director, G H Patel PG Institute of Business Management, Sardar Patel University, Vallabh Vidyanagar, Anand, Gujarat-388120, India.

(C) The Authors. Published by Blue Eyes Intelligence Engineering and Sciences Publication (BEIESP). This is an open access article under the CC BY-NC-ND license (http://creativecommons.org/licenses/by-nc-nd/4.0/) interconnected with telecommunication services day in and day out.

Changes in policy front and entry of new telecom operator like Reliance JIO in Indian Telecom market has ushered in cut throat competition. The telecom market has now become customer centric, where users are the dictators, who are becoming more and more demanding. Hence customer satisfaction has been the prime focus of all telecom operators. Identification of most important parameters related to customer satisfaction from mobile use is the most important aspect. The study is thus quite important in this regard. Mobile users of Gujarat have been chosen as the respondents for identification of most important parameters of satisfaction analysis related to mobile services through Factor Analysis from a set of parameters identified from various sources and through expert opinions.

\section{LITERATURE REVIEW}

Customer satisfaction is one of the prime elements for any Telecom service providers these days in India. It is because of the cut throat competition, which has made Telecom operators more proactive and sensitive towards the customers and their needs. Nurdaulet Nurysh, Navaz Naghavi, Benjamin Chan Yin Fah (2019) have observed that perceived value and service quality has positive relation towards satisfaction quotient of the customers. But, the research has also found that the interaction of both variables with attractiveness of alternatives has no effect to improve or enhance the satisfaction. To examine the important factors such as perceived value and service quality that can directly affect the customer satisfaction, the target population chosen by the researchers had been workers in universities and institutions of Malaysia. Various factors have different levels of impacts on customers. Sendecka and Nysveen (2006), opined that more and more customized, tailor made services that fulfill customer's needs and expectations would lead to a higher level of customer satisfaction. Negi (2009) and Rahman et al. (2011) has found that quality of network has been one of the prime factors of overall customer satisfaction level. In recent times, customer satisfaction has achieved new heights and paradigm shift from transactional marketing to relationship marketing (Sheth, Parvatiyar 1994). Organizations can achieve the goal of customer satisfaction by satisfying their customers' needs and wants (LaBarbera, Mazursky 1983). Customer satisfaction is of judgment level of satisfactory of consumption related pleasure (Oliver 1997). Satisfaction is thus a individual's feelings of happiness or disappointment that originates by comparing a product's perceived values and performance to the anticipated expectation (Oliver, Richard 2006). 
Any deficiency in expectation levels leads to customer dissatisfaction. When performance matches levels of expectations the customer is satisfied and contented. If the performance level exceeds expectation level, the customer becomes extremely joyous and elated (Fournier, Mick 1999). Mobile services providers are investing hefty sum of money but still there is a yawning gap in the actual and perceived value of the customer; A survey which is carried out by Barnhoom C. (2006), has found that although there is progress, nevertheless perceived value from the telecom operators has the lowest score. Langley C. John \& Holcomb Mary C. (1996) opined that companies have the chance to increasing customer satisfaction level through creation of customer value like by providing customers the comparative net value, efficiency level, and feeling of differentiated services. Anderson E. W., Fornell C and Lehmann D. R. (1994), McDougall, G. H. and Levesque T. (2000), Ravald, A. and C. Gronroos (1996) concluded that perceived value is the prime determinant of customer satisfaction.

\section{OBJECTIVE}

This research aims to identify factors of satisfaction of mobile users of Gujarat with respect to the range of the services and supports being offered by various Telecom operators. The study explores the gaps in the 'Customer Expectations' v/s 'Customer Experiences' for the actual services provided by the mobile service providers in Gujarat and identifies the real time issues encountered by the customers. Survey Questionnaire prepared with '5 Point Likert Scale' is analyzed under the Factor Analysis for identifying the factors affecting customer satisfaction. Further the research also evaluates a comparison of satisfaction factors of respondents of various zones of Gujarat, urban vs rural areas of Gujarat and an age wise comparison of satisfaction factors.

\section{RESEARCH METHODOLOGY}

The research is about fulfilling the desired objective. A primary data set composed of questionnaires, focused on 19 different parameters (Table 1.1) of satisfaction related to mobile services was distributed among various mobile users across Gujarat

Table 1.1 Details of the attributes

\begin{tabular}{|c|l|}
\hline Sr No & Attributes \\
\hline 1 & Tariffs and plans \\
\hline 2 & Service activation \\
\hline 3 & Billing complaint \\
\hline 4 & Prompt resolution to billing complaints \\
\hline 5 & Service provider's image \\
\hline 6 & Interruption in voice based services \\
\hline 7 & Responsiveness towards customers \\
\hline 8 & Promptness of coverage complaint resolution \\
\hline 9 & Frequency of call drop and its resolution \\
\hline 10 & Prompt resolution to data service interruption \\
\hline 11 & Voice clarity \\
\hline 12 & Promotional offers \\
\hline 13 & Penetration of franchisee retail network \\
\hline 14 & Helpline and support centers \\
\hline 15 & Internet data service interruptions \\
\hline 16 & Online services \\
\hline 17 & Internet data speed \\
\hline 18 & Coverage of 4G services \\
\hline 19 & Promotional and marketing activities \\
\hline
\end{tabular}

\section{A. Research Design}

Since the study is about identification of factors of satisfaction of Mobile users in Gujarat, the whole mobile user base of all the telecom operators in Gujarat are the prospective population. 800 samples were drawn from this population. The samples were chosen from 20 districts of Gujarat i.e Ahmedabad, Vadodara, Anand, Kheda,Panchmahal,Dahor,Bharuch,Surat,Navsari,Banskatha ,Sabarkatha,Mehsana,Patan,Rajkot,Amreli,Bhavnagar,Jamn agar,Junagadh,Surendranagar and Bhuj. These districts cover 91.2 Per cent of the overall population of Gujarat. Respondents were also chosen based on various age groups, gender, various income groups, locality, qualification and profession etc. The data thus collected helped in getting an insight of the factors related to changing satisfaction level among various mobile users of Gujarat based on various demographic factors like zones, area(urban vs. rural) and ages.

\section{B. Data Collection Methods}

The primary data was collected through interception and interview of the respondents at various societies, market area, retail stores etc. as well as through email.

Table 1.2 Distribution of Respondents

\begin{tabular}{|c|l|}
\hline Sr No & Attributes \\
\hline 1 & Tariffs and plans \\
\hline 2 & Service activation \\
\hline 3 & Billing complaint \\
\hline 4 & Prompt resolution to billing complaints \\
\hline 5 & Service provider's image \\
\hline 6 & Interruption in voice based services \\
\hline 7 & Responsiveness towards customers \\
\hline 8 & Promptness of coverage complaint resolution \\
\hline 9 & Frequency of call drop and its resolution \\
\hline 10 & Prompt resolution to data service interruption \\
\hline 11 & Voice clarity \\
\hline 12 & Promotional offers \\
\hline 13 & Penetration of franchisee retail network \\
\hline 14 & Helpline and support centers \\
\hline 15 & Internet data service interruptions \\
\hline 16 & Online services \\
\hline 17 & Internet data speed \\
\hline 18 & Coverage of 4 G services \\
\hline 19 & Promotional and marketing activities \\
\hline
\end{tabular}

Customer Satisfaction Level was recorded using Likert Scale under 5- Point Scale System. Under Factor Analysis, Principal Component Analysis method was used for the Dimension Reduction and Identification of the Significant Factors for mobile user Satisfaction. Here, 19-attributes measuring the mobile customer Satisfaction with their respective Factor Loadings. Likert scale was derived by the American educator and psychologist R. Likert in the 1920's. Likert statements are generally a Five or Seven point scale. It is used as one of the most basic Psychometric tools in the field of Social Sciences research. 
It is one of the most prominently applied tools for collecting data related to Perception, Attitudes, Values, Intentions, Habits and Behavior changes. In a Likert Scale, the motto of the research is for deriving the opinions/perceptions of participants .On a predetermined scale, every element of Agreement or Disagreement is assigned a numeric value. It can be coded as "1 which stands for Strongly Disagree, 2 stands for Disagreed, 3 stands for Undecided, 4 stands for agreed and 5 stands for Strongly agreed." Factor Analysis is a SEM (Structural Equation Modeling), which measures the variability among Correlated Variables with respect to lower number of Unobserved Variables defined as Factors.

\section{RESULTS AND DISCUSSIONS}

The results are divided into various subsections which are descriptive statistics, reliability analysis and factor analysis

\section{A. Descriptive Statistics}

Descriptive statistics described here the frequency and percentage of profiles of the respondents. Table 1.2 shows that demographic profiles of respondents according to variables like gender, age, profession, income, locality and qualification.

Table 1.3 Demographic factors

\begin{tabular}{|c|c|c|c|}
\hline Factors & Particluars & Frequency & Percentage \\
\hline \multirow[t]{2}{*}{ Gender } & Male & 470 & 58.8 \\
\hline & Female & 330 & 41.3 \\
\hline \multirow[t]{2}{*}{ Area } & Urban & 434 & 54.2 \\
\hline & Rural & 366 & 45.7 \\
\hline \multirow[t]{5}{*}{ Age } & Less than equal to 12 years & 25 & 3.1 \\
\hline & Between 13-25 years & 212 & 26.5 \\
\hline & Between 26 to 40 years & 249 & 31.1 \\
\hline & Between 41 to 60 years & 232 & 29.0 \\
\hline & Greater than 60 years & 82 & 10.3 \\
\hline \multirow[t]{2}{*}{ Marital Status } & Married & 477 & 59.6 \\
\hline & Unmarried & 323 & 40.4 \\
\hline \multirow[t]{8}{*}{ Profession } & Business & 152 & 19.0 \\
\hline & Govt. Service & 124 & 15.5 \\
\hline & Private Service & 194 & 24.3 \\
\hline & Retired & 26 & 3.3 \\
\hline & House wife & 103 & 12.9 \\
\hline & Student & 101 & 12.6 \\
\hline & Farmer & 77 & 9.6 \\
\hline & Unemployed & 23 & 2.9 \\
\hline \multirow[t]{6}{*}{ Annual Income } & Less than Rs. $1,00,000$ & 133 & 16.6 \\
\hline & Rs. $1,00,001-$ Rs. $3,00,000$ & 124 & 15.5 \\
\hline & Rs. $3,00,000$ - Rs. $5,00,000$ & 216 & 27.0 \\
\hline & Rs. $5,00,001-$ Rs. $10,00,000$ & 163 & 20.4 \\
\hline & Above Rs. $10,00,000$ & 72 & 9.0 \\
\hline & Not earning & 92 & $\mathbf{1 1 . 5}$ \\
\hline \multirow[t]{4}{*}{ Qualification } & Post Graduation & 135 & 16.9 \\
\hline & Graduation & 397 & 49.6 \\
\hline & Diploma/ITI & 101 & 12.6 \\
\hline & S.S.C/H.S.C & 167 & 20.9 \\
\hline
\end{tabular}

As far as gender is concerned, 41.3 per cent respondents are female and 58.8 per cent respondents are male.

Classification of respondents age wise shows that 31.13 per cent respondents are of age group 26-40 years, 29 per cent are in age group 41-60 years, 26.5 per cent in age group of 13-25 years , 10.25 per cent in age bracket greater than 60 years and 3.13 per cent are in age group less than 12 years.

It is also found that 59.63 per cent respondents are married while 40.38 per cent respondents are unmarried.

As far as professionals are concerned, 24.25 per cent respondents are in private job, 19 per cent in business, 15.5 per cent in government job, 12.88 per cent house wife, 12.63 per cent students, 9.63 per cent farmers, 3.25 per cent retired person and 2.88 per cent unemployed.

Income bracket of the respondents show that 27 per cent respondents are in 3-5 lakh annual income group, 20.38 per cent in 5-10 lakh income bracket, 16.63 per cent in less than 1 lakh per annum bracket,15.5 per cent between 1-3 lakh and 9 per cent in above 10 lakh bracket.

49.63 per cent respondents are graduates, 20.88 per cent are SSC/HSC qualified, 16.88 per cent are post graduates and 12.63 per cent are Diploma/ITI qualified.

\section{B. Reliability Test}

In this study the main focus is to identify the factors that affect mobile user's satisfaction level. The reliability test shows that Cronbach's Alpha was 0.851 for 19 items. Cronbach's Alpha Coefficient must be greater than 0.65 . Here the value is well above. Therefore, there was internal consistency of the scales and tools used here are highly reliable.

\section{Factor Analysis}

Factor analysis was used to construct the new factors affecting mobile user's satisfaction level. Bartlett's test of sphericity and the Kaiser-Meyer-Olkin measure of sampling adequacy are both tests that can be used to determine the factorability of the matrix as a whole.

\section{Determination of the methods of Factor Analysis}

To carry out factor analysis there are various methods available, among them Principal component method is carried out for our research purpose.

Table 1.4 Appropriateness of Factor Analysis and number of factors

\begin{tabular}{|l|l|r|}
\hline \multicolumn{3}{|c|}{ KMO and Bartlett's Test } \\
\hline Kaiser-Meyer-Olkin Measure of Sampling Adequacy. & $\mathbf{. 7 7 8}$ \\
\hline \multirow{3}{*}{ Bartlett's Test of Sphericity } & Approx. Chi-Square & $\mathbf{8 4 2 7 . 7 0 5}$ \\
\cline { 2 - 3 } & Degree of Freedom & $\mathbf{1 7 1}$ \\
\cline { 2 - 3 } & Significance & $\mathbf{. 0 0 0}$ \\
\hline
\end{tabular}

In the next step, KMO (Kaiser-Meyer-Olikn) Statistic is computed for the Suitability and Sample Adequacy of the data. It is also a measure of the Data Sufficiency. Its value must be 0.7 and above. Here, the KMO measure of sampling adequacy is 0.778 . Barlett's test of Sphericity tests the hypothesis of population correlation matrix vis a vis its identity matrix. Here, the Chi-Square Statistic is 8427.705 with 66 degree of freedom. The value is significant at 95\% Confidence level. Thus, based from the results, it is appropriate to proceed with Factor Analysis to examine factors that affect mobile user's satisfaction level.

\section{Factor Analysis using principal component analysis method}

Communalities indicate the common variance shared by factors with given variables. Higher communality indicated that larger amount of the variance in the variable has been extracted by the factor solution. For better measurement of Factor Analysis, Communalities should be 0.4 or greater. Here, all the Attributes have Communalities greater than 0.4. 
Table 1.5 displays the total variance explained at five stages for factors that affect mobile user's satisfaction level in Gujarat. These five factors were extracted because their Eigen values were greater than 1 . When these five factors were extracted, then 67.398 percent of the Variance would be justified.

\section{Table 1.5 Communalities}

\begin{tabular}{|c|c|c|}
\hline \multicolumn{3}{|l|}{ Communalities } \\
\hline & Initial & Extraction \\
\hline Tariffs and plans & 1.000 & .660 \\
\hline Service activation & 1.000 & .624 \\
\hline Billing complaint & 1.000 & .713 \\
\hline Prompt resolution to billing complaints & 1.000 & .728 \\
\hline Service provider's image & 1.000 & .942 \\
\hline Interruption in voice based services & 1.000 & .663 \\
\hline Responsiveness towards customers & 1.000 & .466 \\
\hline Promptness of coverage complaint resolution & 1.000 & .757 \\
\hline Frequency of call drop and its resolution & 1.000 & .798 \\
\hline Prompt resolution to data service interruption & 1.000 & .628 \\
\hline Voice clarity & 1.000 & .634 \\
\hline Promotional offers & 1.000 & .510 \\
\hline Penetration of franchisee retail network & 1.000 & .525 \\
\hline Helpline and support centers & 1.000 & .507 \\
\hline Internet data service interruptions & 1.000 & .542 \\
\hline Online services & 1.000 & .647 \\
\hline Internet data speed & 1.000 & .823 \\
\hline Coverage of $4 \mathrm{G}$ services & 1.000 & .711 \\
\hline Promotional and marketing activities & 1.000 & .927 \\
\hline
\end{tabular}

Table 1.6 Total Variance Explained: Extraction Method Principal Component Analysis.

\begin{tabular}{|c|c|c|c|}
\hline \multirow{2}{*}{ Component } & \multicolumn{3}{|c|}{ Initial Eigenvalues } \\
\cline { 2 - 4 } & Total & $\begin{array}{c}\text { Variance } \\
\text { \% }\end{array}$ & $\begin{array}{c}\text { Cumulative } \\
\text { \% }\end{array}$ \\
\hline 2 & 5.633 & 29.650 & 29.650 \\
\hline 3 & 2.457 & 12.931 & 42.581 \\
\hline 4 & 1.888 & 9.939 & 52.520 \\
\hline 5 & 1.517 & 7.982 & 60.502 \\
\hline 6 & 1.310 & 6.897 & 67.398 \\
\hline 7 & .966 & 5.085 & 72.483 \\
\hline 8 & .818 & 4.308 & 76.791 \\
\hline 9 & .767 & 4.038 & $\mathbf{8 0 . 8 2 9}$ \\
\hline 10 & .624 & 3.286 & $\mathbf{8 4 . 1 1 4}$ \\
\hline 11 & .484 & 2.548 & $\mathbf{8 6 . 6 6 3}$ \\
\hline 12 & .476 & 2.503 & $\mathbf{8 9 . 1 6 6}$ \\
\hline 13 & .412 & 2.170 & 91.336 \\
\hline 14 & .399 & 2.100 & 93.436 \\
\hline 15 & .324 & 1.705 & 95.141 \\
\hline 16 & .306 & 1.609 & 96.750 \\
\hline 17 & .234 & 1.232 & 97.982 \\
\hline 18 & .172 & .906 & 98.888 \\
\hline 19 & .162 & .851 & 99.739 \\
\hline & .050 & .261 & 100.000 \\
\hline
\end{tabular}

\begin{tabular}{|c|c|c|c|}
\hline \multicolumn{4}{|c|}{ Rotation Sums of Squared Loadings } \\
\hline Component & Total & Variance (\%) & Cumulative (\%) \\
\hline 1 & 4.141 & 21.794 & 21.794 \\
\hline 2 & 2.504 & 13.179 & 34.973 \\
\hline 3 & 2.236 & 11.769 & 46.742 \\
\hline 4 & 2.195 & 11.552 & 58.294 \\
\hline 5 & 1.730 & 9.105 & 67.398 \\
\hline
\end{tabular}

\begin{tabular}{|c|c|c|c|}
\hline \multicolumn{4}{|c|}{ Extraction Sums of Squared Loadings } \\
\hline Component & Total & Variance (\%) & Cumulative (\%) \\
\hline 1 & 5.633 & 29.650 & 29.650 \\
\hline 2 & 2.457 & 12.931 & 42.581 \\
\hline 3 & 1.888 & 9.939 & 52.520 \\
\hline 4 & 1.517 & 7.982 & 60.502 \\
\hline 5 & 1.310 & 6.897 & 67.398 \\
\hline
\end{tabular}

Table 1.7 shows the rotated factor matrix for the desired questionnaire. Tabachnick and Fidell [28] opined that variable with factor loadings more than 0.45 be chosen in this study because loadings equals to 0.45 is understood to be average, whereas loadings 0.32 is considered to be not so good. After performing Varimax Rotation Method with Kaiser Normalization, Factor 1 comprised of seven items with factor loadings ranging from 0.55 to 0.84 . Factor 2 comprised of four items with factor loadings ranging from 0.46 to 0.87 . Factor 3 comprised of two items with factor loadings of 0.936 and 0.949 . Factor 4 comprised of three items with factor loadings ranging from 0.53 to 0.82 . Factor 5 comprised of three items with factor loadings ranging from 0.56 to 0.61 .

\section{Table 1.7 Rotated Component Matrix}

\begin{tabular}{|l|c|c|c|c|c|}
\hline \multicolumn{5}{|c|}{ Rotated Component Matrix } \\
\hline & \multicolumn{5}{|c|}{ Component } \\
\hline & 1 & 2 & 3 & 4 & 5 \\
\hline Promptness of coverage complaint resolution & .841 & & & & \\
\hline Frequency of call drop and its resolution & .838 & & & & \\
\hline Voice clarity & .761 & & & & \\
\hline Prompt resolution to data service interruption & .681 & & & & \\
\hline Interruption in voice based services & .636 & & & & \\
\hline Responsiveness towards customers & .592 & & & & \\
\hline Service activation & .557 & & & & \\
\hline Internet data speed & & .873 & & & \\
\hline Coverage of 4G services & & .781 & & & \\
\hline Online services & & .669 & & & \\
\hline Internet data service interruptions & & .460 & & & \\
\hline Service provider's image & & & .949 & & \\
\hline Promotional and marketing activities & & & .936 & & \\
\hline Billing complaint & & & & .820 & \\
\hline Prompt resolution to billing complaints & & & & .798 & \\
\hline Tariffs and plans & & & & .536 & \\
\hline Penetration of franchisee retail network & & & & & .616 \\
\hline Promotional offers & & & & & .616 \\
\hline Helpline and support centers & & & & & .564 \\
\hline $\begin{array}{l}\text { Extraction Method: Principal Component Analysis. } \\
\text { Rotation Method: Varimax with Kaiser Normalization. }\end{array}$ & & & & \\
\hline a. Rotation converged in 8 iterations. & & & & \\
\hline
\end{tabular}

\section{Interpretation of Factors}

\section{Factor Number 1}

Analysis of rotated component matrix at Table 1.7 highlights that "Promptness of coverage complaint resolution", "Frequency of call drop and its resolution", "Voice clarity" , "Prompt resolution to data service interruption", "Faults in voice based services" ,"Responsiveness towards customers" and "Service activation" have loading factors of $0.841,0.838,0.761,0.681,0.636,0.592$ and 0.557 respectively. This highlights to the fact that factor 1 is a combination of seven variables. Hence factor 1 can be phrased as "Prompt service delivery and responsiveness of service providers".

\section{Factor Number 2}

Analysis of rotated component matrix at Table 1.7 shows that" Internet data speed", "Coverage of $4 \mathrm{G}$ services", "Online services" and "Internet data service interruptions" have loading factors of $0.873,0.781,0.669$ and 0.460 respectively. This points to the fact that factor 2 is a combination of four variables. Hence factor 2 can be phrased as "High speed internet service".

Published By:

Blue Eyes Intelligence Engineering \& Sciences Publication

(C) Copyright: All rights reserved. 


\section{Factor Number 3}

Rotated component matrix at Table 1.7 highlights that "service provider's image" and "promotional and marketing activities" have loading factors of 0.949 and 0.946 respectively. This highlights to the fact that factor 3 is a combination of two variables. Hence factor 3 can be phrased as "Image of service provider".

\section{Factor Number 4}

Analysis of rotated component matrix shows that Occurrence of "Billing complaint", "Prompt resolution to billing complaints" and "tariffs \& plans" have loading factors of $0.820,0.798$ and 0.536 respectively. This means that factor 4 is a combination of three variables. Hence factor 4 can be phrased as "Billing performance".

\section{Factor Number 5}

"Penetration of franchisee retail network"," Promotional offers" and "Helpline and support" have loading factors of $0.616,0.616$ and 0.564 respectively. This points to the fact that factor 5 is a combination of three variables. Hence factor 5 can be phrased as "Customer support".

Table 1.8 Factors and its associated Names

\begin{tabular}{|l|l|l|c|}
\hline Sr $\mathrm{N}_{0}$ & Factor & Name on the basis of inferences & Percentage of Variance \\
\hline 1 & Factor 1 & $\begin{array}{l}\text { Prompt Service Delivery and responsiveness of } \\
\text { Service Provider }\end{array}$ & 29.650 \\
\hline 2 & Factor 2 & High Speed Internet Service & 12.931 \\
\hline 3 & Factor 3 & Image of Service Provider & 9.939 \\
\hline 4 & Factor 4 & Billing Performance & 7.982 \\
\hline 5 & Factor 5 & Customer Support & 6.897 \\
\hline
\end{tabular}

The Scree plot displays the number of the factor w.r.t. its corresponding Eigen value. The Scree plot arranges the Eigen values from largest to smallest. It explains the first five factors, having Eigen value greater than 1, for the Total Variability in data (given by the Eigen values).

Scree Plot

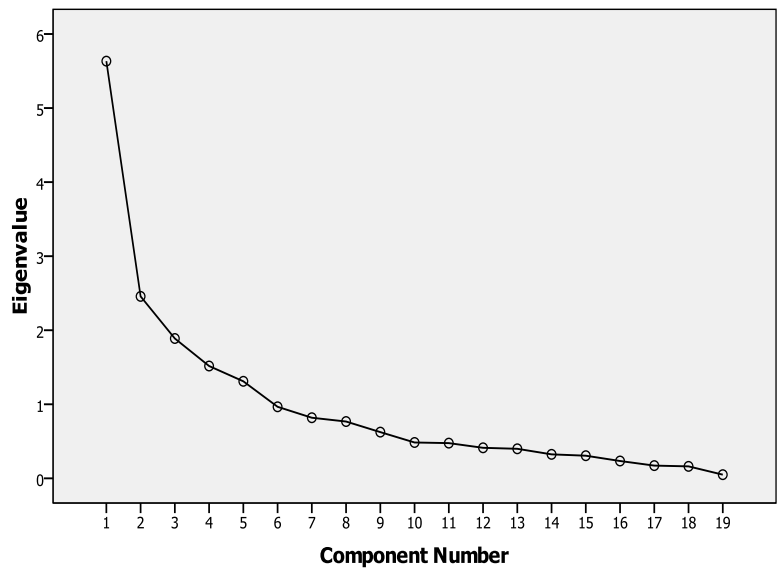

Figure 1.1 Scree Plot
Table 1.9 Zone wise Customer Satisfaction

\begin{tabular}{|c|c|c|c|c|c|c|c|c|c|}
\hline Particulars & $\begin{array}{c}\text { Central } \\
\text { Gujarat } \\
\% \\
\end{array}$ & $\begin{array}{l}\text { Factor } \\
\text { Avg } \\
\% \\
\end{array}$ & \begin{tabular}{|c|} 
North \\
Grijart \\
$\%$
\end{tabular} & $\begin{array}{l}\text { Factor } \\
\text { Avg } \\
\% \\
\end{array}$ & $\begin{array}{c}\text { Saurastra } \\
\%\end{array}$ & $\begin{array}{l}\text { Factor } \\
\text { Avg } \\
\% \\
\end{array}$ & $\begin{array}{c}\text { South } \\
\text { Gujarat } \\
\% \\
\end{array}$ & \begin{tabular}{|l} 
Factor \\
Avg \\
$\%$ \\
\end{tabular} & $\begin{array}{c}\text { Factor } \\
\text { Designation }\end{array}$ \\
\hline Promptness of coverage complaint resolution & 59,8 & \multirow{7}{*}{63.1} & 73.2 & \multirow{7}{*}{60.8} & 58.9 & \multirow{7}{*}{62.5} & 65.3 & \multirow{7}{*}{69.4} & \multirow{7}{*}{ Factor 1} \\
\hline Frequency of call drop and its resolution & 67.2 & & 65 & & 76.2 & & 87,1 & & \\
\hline Voice clarity & 69.5 & & 56.9 & & 67.3 & & 79 & & \\
\hline Prompt tesolution to data service intermption & 64.1 & & 46.3 & & 57.4 & & 79,8 & & \\
\hline Faults in voice based services & 72.1 & & 72.4 & & 65.8 & & 66.9 & & \\
\hline Responsiveness towards customers & 58.7 & & 61 & & 58.9 & & 57.3 & & \\
\hline Service activation & 50.7 & & 51.2 & & 53 & & 50.8 & & \\
\hline Intemet data speed & 57.3 & \multirow{4}{*}{56.9} & 56.9 & \multirow{4}{*}{53.4} & 76.2 & \multirow{4}{*}{78.8} & 83.1 & \multirow{4}{*}{79.6} & \multirow{4}{*}{ Factor? } \\
\hline Coverage of $4 G$ services & 58.7 & & 52 & & 78.2 & & 78.2 & & \\
\hline Online services & 62.1 & & 61.8 & & 87,1 & & 87.9 & & \\
\hline Intemet data service intemuptions & 49.6 & & 43.1 & & 73.8 & & 69.4 & & \\
\hline Service provider's image & 51.3 & \multirow[t]{2}{*}{54.1} & 48.1 & \multirow[t]{2}{*}{33.8} & 60.4 & \multirow[t]{2}{*}{61.9} & 80.6 & \multirow[t]{2}{*}{82.6} & \multirow[t]{2}{*}{ Factor 3} \\
\hline Promotional and marketing activities & 57 & & 19.5 & & 63.4 & & 84.7 & & \\
\hline Occurrence of Billing conplaint & 64.4 & \multirow{3}{*}{61.5} & 17,9 & \multirow{3}{*}{26.5} & 69.3 & \multirow{3}{*}{63.8} & 86.3 & \multirow{3}{*}{86.7} & \multirow{3}{*}{ Factor 4} \\
\hline Prompt resolution to billing Complaints & 53.8 & & 20.3 & & 54 & & 85.2 & & \\
\hline Tariffs and plans & 66.4 & & 41.5 & & 68.3 & & 88.7 & & \\
\hline Penetration of franchisee ertail network & 60.7 & \multirow{3}{*}{68} & 50.4 & \multirow{3}{*}{57.73} & 65.8 & \multirow{3}{*}{65.8} & 86.3 & \multirow{3}{*}{82.4} & \multirow{3}{*}{ Factor 5} \\
\hline Promotional offers & 71.2 & & 50.4 & & 65.8 & & 94 & & \\
\hline Hebline and support centers & 72.1 & & 72.4 & & 65.8 & & 66.9 & & \\
\hline
\end{tabular}

The respondents in this study were chosen from 4 different zones of Gujarat. Their responses towards satisfaction and with respect to the factored parameters of satisfaction from mobile services are tabulated in Table 1.9.

Analysis of the above data suggests that customer satisfaction in Prompt service delivery and responsiveness of service provider is best in South Gujarat while in north Gujarat the satisfaction level is worst. Satisfaction in terms of high speed internet services is again supreme in south Gujarat while north Gujarat stands in the bottom in this regard. In all the other parameters, like image of the service provider, billing performance and in terms of customer support, south Gujarat reigns supreme and North Gujarat is in the bottom of the rung.

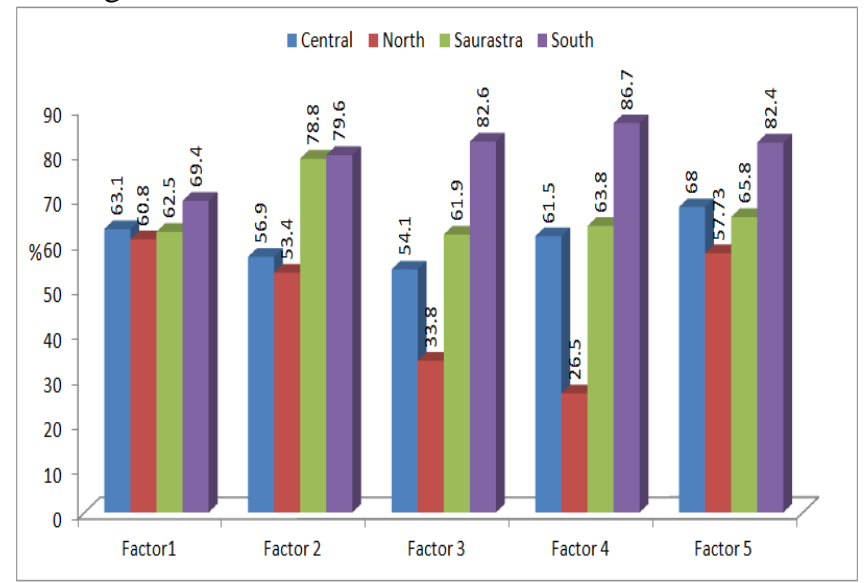

Figure 1.2 Zone wise satisfaction analysis (in Percent)

\section{b. Based on Urban and Rural areas}

The respondents in this study were chosen from various urban and rural areas of Gujarat. Their responses towards satisfaction and with respect to the factored parameters of satisfaction from mobile services are tabulated in Table 1.10.

\section{Analysis of Satisfaction}

\section{a . Based on various zones of Gujarat}




\section{Measuring Mobile Service Satisfaction: Factor Analysis Based Study on Mobile Users of Gujarat}

Table 1.10 Area wise Customer Satisfaction

\begin{tabular}{|c|c|c|c|c|c|}
\hline Particulars & $\begin{array}{c}\text { Urban } \\
\%\end{array}$ & $\begin{array}{c}\text { Factor } \\
\text { Average }\end{array}$ & $\begin{array}{c}\text { Rural } \\
\%\end{array}$ & $\begin{array}{c}\text { Factor } \\
\text { Average }\end{array}$ & $\begin{array}{c}\text { Factor } \\
\text { Description }\end{array}$ \\
\hline Promptness of coverage complaint resolution & 67.5 & \multirow{7}{*}{67.4} & 46.8 & \multirow{7}{*}{60.4} & \multirow{7}{*}{ Factor 1} \\
\hline Frequency of call drop and its resolution & 78.3 & & 67.5 & & \\
\hline Voice clarity & 78.6 & & 64.1 & & \\
\hline Prompt resolution to data service interruption & 65.7 & & 63.7 & & \\
\hline Faults in voice based services & 71.2 & & 68.8 & & \\
\hline Responsiveness towards customers & 58.8 & & 59 & & \\
\hline Service Activation & 52.1 & & 52.9 & & \\
\hline Internet data speed & 69.1 & \multirow{4}{*}{68} & 65.4 & \multirow{4}{*}{63} & \multirow{4}{*}{ Factor 2} \\
\hline Coverage of $4 \mathrm{G}$ services & 69.8 & & 61.4 & & \\
\hline Online services & 74.4 & & 70.8 & & \\
\hline Internet data service interruptions & 59 & & 56.3 & & \\
\hline Service provider"s image & 58.8 & \multirow[b]{2}{*}{62.7} & 58.3 & \multirow[t]{2}{*}{52.3} & \multirow[t]{2}{*}{ Factor 3} \\
\hline Promotional and marketing activities & 66.6 & & 46.4 & & \\
\hline Occurrence of Billing complaint & 69.8 & \multirow{3}{*}{68.4} & 53.6 & \multirow{3}{*}{54} & \multirow{3}{*}{ Factor 4} \\
\hline Prompt resolution to billing complaints & 60.8 & & 46.8 & & \\
\hline Tariffs and plans & 74.7 & & 61.7 & & \\
\hline Penetration of franchisee retail network & 67.1 & \multirow{3}{*}{72.7} & 62.7 & \multirow{3}{*}{63.7} & \multirow{3}{*}{ Factor 5} \\
\hline Promotional Offers & 80 & & 59.7 & & \\
\hline Helpline and Support Centers & 71.2 & & 68.8 & & \\
\hline
\end{tabular}

Analysis of above table suggests that satisfaction level of mobile users in rural areas in terms of prompt service delivery and responsiveness of service providers, high speed internet service, image of service provider, billing performance and customer support vis-à-vis urban area is lacking. Out of all the factors, image of service providers in the eyes of the respondents and billing performance in rural area is significantly lacking. Telecom service providers need to work judiciously to improve these factors in rural areas to increase tele density in the rural bands.

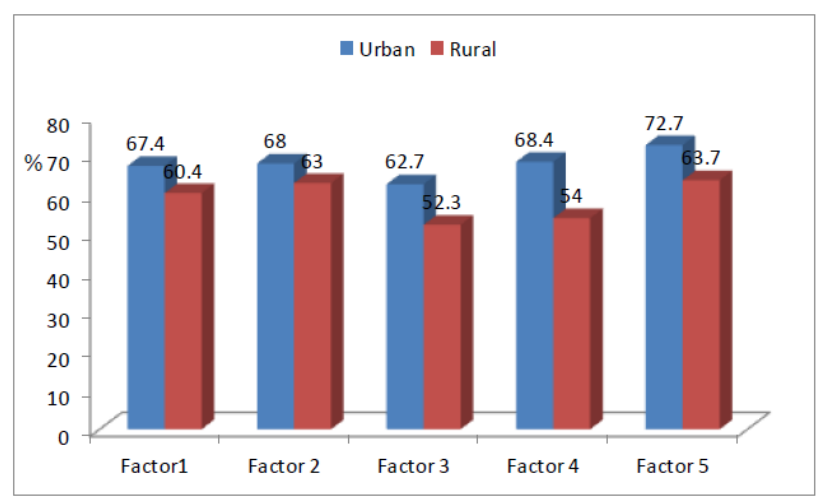

Figure 1.3 Area wise satisfaction Analysis

\section{c. Based on Age groups}

The respondents in this study were divided in four age groups. Their responses towards satisfaction and with respect to the factored parameters of satisfaction from mobile services are tabulated in Table 1.11

Table 1.11 Age group wise Customer Satisfaction

\begin{tabular}{|c|c|c|c|c|c|c|c|c|c|}
\hline Particulars & $\begin{array}{c}13-25 \\
\text { years } \\
\% \\
\end{array}$ & \begin{tabular}{|c|} 
Factor \\
Arg \\
$\%$ \\
\end{tabular} & \begin{tabular}{|c|}
$26-40$ \\
years \\
$\%$ \\
\end{tabular} & \begin{tabular}{|c|} 
Factor \\
$\mathrm{Arg}$ \\
$\%$ \\
\end{tabular} & $\begin{array}{c}11-60 \\
\text { years } \\
\%\end{array}$ & \begin{tabular}{|c|} 
Factor \\
Arg \\
$\%$ \\
\end{tabular} & $\begin{array}{c}>60 \\
\text { years } \\
\%\end{array}$ & \begin{tabular}{|c|} 
Factor \\
$\mathrm{drg}$ \\
$\%$ \\
\end{tabular} & $\begin{array}{c}\text { Factor } \\
\text { Designation }\end{array}$ \\
\hline Promptness of coverage complaint resolution & 68.9 & \multirow{7}{*}{56.5} & 59.4 & \multirow{7}{*}{72} & 72 & \multirow{7}{*}{55.9} & 79.3 & \multirow{7}{*}{78.8} & \multirow{7}{*}{ Factor 1} \\
\hline Frequency of call drop and its resolution & 74.1 & & 76.3 & & 57.8 & & 91.5 & & \\
\hline Voice clarity & 65.6 & & 76.7 & & 54.7 & & 90.2 & & \\
\hline Prompt resolution to data service intermption & 51.4 & & 71.9 & & 50.9 & & 76 & & \\
\hline Faults in voice based services & 47.2 & & 92.4 & & 57.3 & & 85.4 & & \\
\hline Responsiveness towards customers & 45.3 & & 68.7 & & 51.7 & & 73.2 & & \\
\hline Service activation & 43.4 & & 58.6 & & 47 & & 56.1 & & \\
\hline Intemet data speed & 73.1 & \multirow{4}{*}{70.5} & 71.9 & \multirow{4}{*}{69.8} & 53.9 & \multirow{4}{*}{54.8} & 62.2 & \multirow{4}{*}{64.9} & \multirow{4}{*}{ Factor 2} \\
\hline Coverage of $4 \mathrm{G}$ services & 72.6 & & 68.7 & & 55.6 & & 64.6 & & \\
\hline Online services & 78.3 & & 76.7 & & 61.2 & & 67.1 & & \\
\hline Intemet data service intermptions & 58 & & 62.2 & & 48.7 & & 65.9 & & \\
\hline Service provider's image & 56.6 & \multirow[t]{2}{*}{51.6} & 73.5 & \multirow[t]{2}{*}{69.1} & 53 & \multirow[t]{2}{*}{51.05} & 31.7 & \multirow[t]{2}{*}{60.35} & \multirow[t]{2}{*}{ Factor 3} \\
\hline Promotional and marketing activities & 46.7 & & 64.7 & & 49.1 & & 89 & & \\
\hline Occurrence of Billing complaint & 51.4 & \multirow{3}{*}{53.7} & 76.7 & \multirow{3}{*}{73.3} & 60.3 & \multirow{3}{*}{55.4} & 54.9 & \multirow{3}{*}{60.5} & \multirow{3}{*}{ Factor 4} \\
\hline Prompt resolution to billing Complaints & 49.5 & & 64.7 & & 51.7 & & 40.2 & & \\
\hline Tariffs and plans & 60.4 & & 78.7 & & 54.3 & & 86.6 & & \\
\hline Penetration of franchisee retail network & 58.5 & \multirow{3}{*}{59.4} & 77.1 & \multirow{3}{*}{85} & 50 & \multirow{3}{*}{51} & 87.8 & \multirow{3}{*}{89.4} & \multirow{3}{*}{ Factor 5} \\
\hline Promotional offers & 72.6 & & 85.5 & & 45.7 & & 95.1 & & \\
\hline Hepline and support centers & 47.2 & & 92.4 & & 57.3 & & 85.4 & & \\
\hline
\end{tabular}

The responses show that the elderly (greater than 60 years) are more satisfied towards Prompt service delivery and responsiveness of service providers' i.e factor 1 and customer support of their service providers' i.e factor 5 than any other age groups. The younger brigade (between 13-25 years) is the most satisfied age group towards high speed internet services of their service providers i.e factor 2. People in the age group of 26-40 years are most satisfied in terms of satisfaction towards the image and billing performance of their service providers.

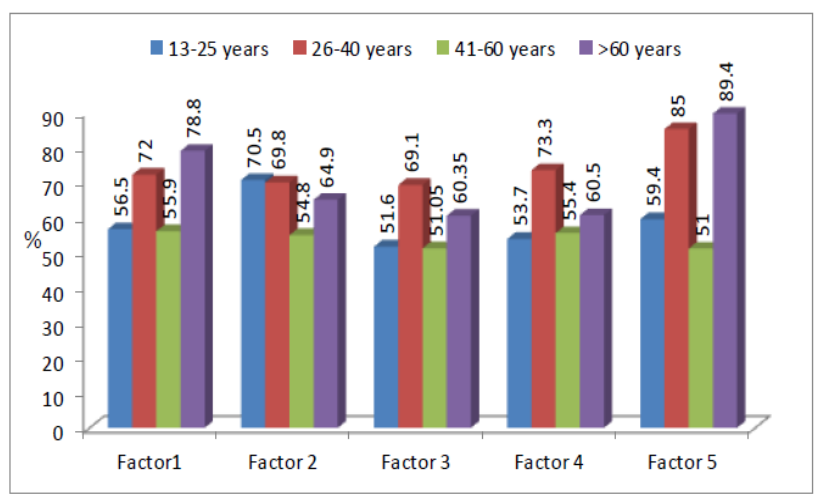

Figure 1.4 Age group wise satisfaction Analysis

\section{CONCLUSION AND FUTURE SCOPES}

Under Factor Analysis, Significant Factors for parameters of satisfaction for mobile users were identified. Here, 19 Attributes were grouped under 5 factors, with their respective Factor Loadings. This study has revealed that the significant factors (Prompt service delivery and responsiveness of service provider, High speed internet service, Image of service provider, Billing performance and Customer support) are significant for mobile users satisfaction in Gujarat. It identifies the Service gaps between customer expectations v/s customer experiences. Enhancement of customer experience quality and satisfaction are the key issues for sustainability of telecom service providers. These findings will be useful to the telecom operators for enhancing the quality of service and improvement of their image. Analysis and implementation of the factors by the telecom companies can add towards customer acquisition and customer retention. From the perception analysis of the respondents from various zones of Gujarat suggests that South Gujarat region scored heavily in terms of mobile customer satisfaction compared to all the other zones. These observations can be quite handy for the telecom operators to plan and devise strategies related to sales and marketing along with optimization of mobile network .A comparative study of urban and rural Gujarat has clearly suggested that perceived satisfaction level of respondents belonging to rural areas are far less than their urban counterparts, which suggests that QOS at rural areas are not at par compared to the cities. This may be one of the very reasons of the yawning gap between urban and rural teledensity. As far as age wise analysis are concern, it is seen that young brigade are the most satisfied lot of high speed internet services compared to all other age groups.

Published By:

Blue Eyes Intelligence Engineering \& Sciences Publication

(C) Copyright: All rights reserved.

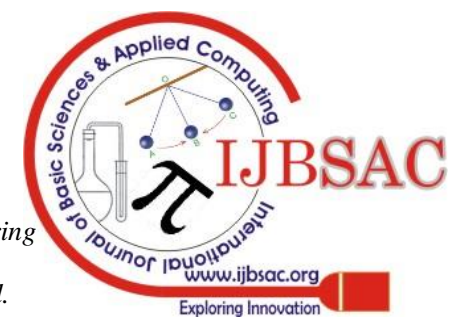


Telecom operators may plan some innovative measures like tariff plans, improved quality of service to increase the perceived satisfaction level of middle aged and senior citizens towards high speed internet services.

\section{REFERENCES}

1. Anderson, E. W., Fornell, C. and Lehmann, D. R. (1994). "Customer Satisfaction, Market Share, And Profitability: Findings From Sweden". The Journal of Marketing, 58(3), pp.53-66.

2. Barnhoom, C., (2006). "Customer satisfaction increases in the Telecommunications industry". Synovate Research Reinvented.

3. Chen A. H., et. al (2011). "The Causes of Customer Satisfaction in Telecommunication Services: An Empirical Study". Proceedings of the 7th International Conference on Advanced Information Management and Service.

4. Chen A., Lu, Y. Gupta, S. and Xiaolin,(2014). "Can Customer Satisfaction And Dissatisfaction Coexist? An Issue of Telecommunication Service in China". Journal of Information Technology, 29(3), pp.237-52. 5. Cheng, N., (2016).

5. Dehghan, A.; Zenouzi, B.; Albadvi, A. 2012. An investigation on the relationship between service quality and customer satisfaction: in the case of CCG CO, International Business Research 5(1): 3-8.

6. Fornell, C.; Westbrook, R. A. 1984. The vicious circle of consumer complaints, Journal of Marketing 48(3): 68-78. http://dx.doi.org/10.2307/1251330

7. Lawlay, D. N. \& Maxwell, A. E. (1963), Factor Analysis as a Statistical Method. London: Butterworth.

8. R. A. Johnson and D. W. Wichern, Applied Multivariate Statistical Analysis. Fifth Edition. Prentice-Hall, Inc, Upple Saddle River, 2002

9. Carver, R. H. \& Nash, J. G., Doing Data Analysis with SPSS. Thomson Brooks/Cole, Belmont, 2006.

10. Churchill, G. A. \& Surprenant, C. (1982). An investigation into the determinants of customer satisfaction. Journal of Marketing Research, 19(3), 491-504.

11. Folkes, V.S. (1984). Consumer Reaction to Product Failure: An attributional approach. Journal of Consumer Research, 398-409.

12. Fornell, C. (1992). A National Customer Satisfaction Barometer: The Swedish Experience. Journal of Marketing, 56(1), 6-21.

13. Nurdaulet Nurysh, Navaz Naghavi, Benjamin Chan Yin Fah (2019). Study on Factors Affecting Customer Satisfaction in Mobile Telecommunication Industry in Malaysia, International Journal of Recent Technology and Engineering (IJRTE).ISSN: 2277-3878, Volume-7. Issue-5S. January 2019.

14. Md. Danish, Manjari Chakraborty.(2019). Measuring the Tourist Service Satisfaction: Factor Analysis based Study at Red Fort Complex.International Journal of Recent Technology and Engineering (IJRTE). ISSN: 2277-3878, Volume-7 Issue-5S, January 2019.

15. Negi, R. (2009). Determining customer satisfaction through perceived service quality: a study of Ethiopian mobile users. International Journal of Mobile Marketing, 4(1): 31-38

16. Jagdish N.Sheth, Atul Parvatiya.(1995). The evolution of relationship marketing .International Business Review,Volume 4, Issue 4, 1995, Pages 397-418.

17. La Barbera, P.A. and Mazursky, D. (1983). A Longitudinal Assessment of Consumer Satisfaction/Dissatisfaction: The Dynamic Aspect of the Cognitive Process. Journal of Marketing Research,20, 393-404. http://dx.doi.org/10.2307/3151443

18. BasriModding2, Baharuddin Semmaila2, Achmad Gani2.(2016). Journal of Business and Management Sciences, , Vol. 4 No. 4, 76-81

19. SUSAN FOURNIER, DAVID GLEN MICK.(1999).REDISCOVERING SATISFACTION, VOLUME: 63 ISSUE: 4, PAGE(S): 5-23

20. Eugene W. Anderson, Claes Fornell and Donald R. Lehmann.(1994). Customer Satisfaction, Market Share, and Profitability: Findings from Sweden. Journal of Marketing. Vol. 58, No. 3 (Jul., 1994), pp. 53-66

21. https://www.census2011.co.in/census/state/districtlist/gujarat.html

22. Gordon H.G.Mcdougall,Terrence Levesque,(2000)"Customer Satisfaction with services:putting perceived value into the equation",Journal of services marketing,Vol.14 Issue:5,pp.392-410,http://Doi.Org/10.1108/08876040010340937

23. Annika Ravald, Christian Grönroos, (1996) "The value concept and relationship marketing", European Journal of Marketing, Vol. 30,Issue:2 , pp.19-30, https://doi.org/10.1108/03090569610106626

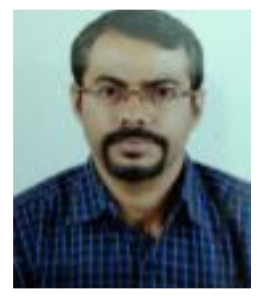

\section{AUTHORS PROFILE}

Sukanta Saha, has done his engineering in Electronics and completed his MBA in Finance and currently persuing his Ph.D in Management from Sardar Patel University, Vallabh Vidynagar, Gujarat and has already submitted his Ph.D. thesis. He has an Industrial experience of nearly 15 years in Telecom Domain and has keen interest is Telecom Marketing and Risk Management. He can be reached at ssahacc@gmail.com

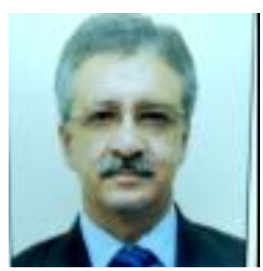

Yogesh C Joshi, is Dean, Faculty of Management, Director, G H Patel PG Institute of Business Management, Sardar Patel University, Vallabh Vidyanagar Anand, Gujarat. He has done his Ph.D.in Economics and has more than 20 years of teaching experience. He has more than 90 publications in various journals of international reputes and has successfully guided $20 \mathrm{Ph} . \mathrm{D}$. students. He has attended various seminars and conferences around the world and has visited Norway, Netherlands, Maldives, Srilanka and Bhutan, amongst others. He can be reached at joshiyogesh_2000@yahoo.com.

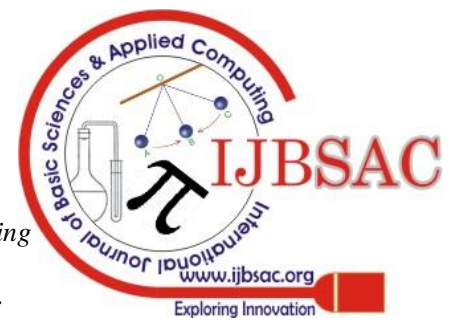

